\title{
FENOMEN WCZESNEJ IMITACJI. BADANIE REAKCJI ODZWIERCIEDLANIA U NOWORODKÓW JAKO KRYTERIUM DIAGNOSTYCZNE DO IDENTYFIKACJI DZIECI ZAGROŻONYCH AUTYZMEM
}

\section{THE PHENOMENON OF EARLY IMITATION. RESEARCH ON THE MIRRORING REACTION IN NEWBORNS AS A DIAGNOSTIC CRITERION FOR IDENTIFYING CHILDREN AT RISK OF AUTISM}

\section{Dorota Prędkiewicz}

Wydział Nauk Stosowanych, Dolnośląska Szkoła Wyższa we Wrocławiu

https://orcid.org/0000-0001-5240-4929

DOI: https://doi.org/10.20883/pielpol.2021.11

\section{STRESZCZENIE}

Wstęp. Jednym z charakterystycznych zachowań dzieci z autyzmem jest brak rozwoju kontaktu wzrokowego i zainteresowania ludzką twarzą. Amerykański psycholog Andrew Meltzoff udowodnił, że noworodki wykazują prymitywną zdolność do imitowania ruchów twarzy swoich opiekunów. Ta umiejętność związana jest z wrodzoną aktywnością neuronów lustrzanych. Natomiast naturalna zdolność do imitacji odgrywa bardzo ważną rolę w dalszym rozwoju społecznym i poznawczym.

Cel. Sprawdzenie związku pomiędzy brakiem reakcji odzwierciedlania w okresie noworodkowym a zaburzeniami ze spektrum autyzmu w dalszym rozwoju dziecka.

Materiał i metody. Badaniem objęto losową grupę 350 noworodków. Spośród tej grupy wyłoniono 10 noworodków nieodzwierciedlających oraz utworzono grupę kontrolną z 20 losowo wybranymi noworodkami odzwierciedlającymi. Następnie porównano sytuację rodzinną i zdrowotna w obu grupach w celu wykrycia czynników mogących wpływać na reakcję odzwierciedlania. Metodą badawczą był sondaż diagnostyczny z techniką wywiadu ustrukturyzowanego, uzupełnionego analizą dokumentacji medycznej. Do sprawdzenia rozwoju dzieci w obu grupach w 18. miesiącu życia wykorzystano „Karty diagnozy - 10 etapów rozwoju dziecka od 4. do 36. miesiąca życia” J. Cieszyńskiej, M. Korendo. Analiza statystyczna: IBM SPSS Statistics, test niezależności chi-kwadrat $(p<0,05)$.

Wyniki i wnioski. Większość mierzonych związków jest nieistotna statystycznie. Związek pomiędzy reakcją odzwierciedlania a: wiekiem matek i ojców ( $p=0,939)$; wykształceniem matek ( $p<$ $0,05)$ i ojców $(p=0,797)$; ciążą wysokiego ryzyka $(p=0,784)$; wcześniactwem $(p=1,000)$; rodzajem porodu $(p=0,823)$; stanem zdrowia noworodka $(p=0,823)$. Jednak badanie dzieci w 18 . miesiącu życia potwierdziło istniejącą korelację pomiędzy brakiem reakcji odzwierciedlania w okresie noworodkowym a dalszym rozwojem w kierunku autyzmu.

SŁOWA KLUCZOWE: autyzm, imitacja, reakcja odzwierciedlania, neurony lustrzane, rozwój.

\section{ABSTRACT}

Introduction. One of the characteristic behaviors of children with autism is the lack of development of eye contact and interest in the human face. An American psychologist, A. Meltzoff, proved that newborns had a primitive ability to imitate the facial movements of their caregivers. This skill is associated with the innate activity of mirror neurons. However, the inborn ability to imitate plays a very important role in further social development. Aim. The aim of the study was to check the relationship between the lack of mirroring in the neonatal period and autism spectrum disorders in the further development of the child.

Material and methods. The study covered a randomly selected group of 350 newborns. From this group, ten newborns that did not show mirroring reactions were selected and a control group was created from 20 randomly selected newborns that showed mirroring reactions. The family and health situation in both groups was then compared in order to detect the factors that might affect the mirroring reaction. The research method was a diagnostic survey with a structured interview technique supplemented by analysis of medical records. To check the development of children in both groups at 18 months of age, "Diagnosis cards of 10 stages of child development from 4 to 36 months of age" by J. Cieszynska, M. Korendo were used. Statistical analysis: IBM SPSS Statistics, chi-quadrant independence test $(p<0.05)$.

Results and conclusions. Most of the measured compounds are statistically insignificant. Relationship between the lack of mirroring reactions and: age of mothers and fathers $(p=0,939)$; education of mothers $(p<0.05)$ and fathers $(p=0.797)$; high-risk pregnancy $(p=0,784)$; prematurity $(p=1.000)$; type of birth $(p=$ $0.823)$; state of health of the newborn ( $p=0,823)$.

However, the study of children in the 18th month of life confirmed the existing correlation between the lack of mirroring reactions in the neonatal period and further development towards autism.

KEYWORDS: autism, imitation, mirroring reaction, mirror neurons, development. 


\section{Wstęp}

Autyzm jest zaburzeniem neurorozwojowym, które pomimo wspólnych cech charakteryzuje się dużym zróżnicowaniem i dynamiką zmian. Szacuje się, że zaburzenia rozwojowe w kierunku autystycznego spektrum występują u jednego na sześćdziesiąt osiem dzieci, a średni wiek diagnozy autyzmu to 4 lata [1]. Klinicznie diagnoza stawiana jest na podstawie tzw. triady autystycznej: zaburzenia komunikacji werbalnej i niewerbalnej, zaburzenia interakcji społecznej oraz ograniczone, powtarzające się wzorce zachowania, aktywności i zainteresowań [2]. Dzieci z autyzmem manifestują brak lub ograniczony rozwój kontaktu wzrokowego z inną osobą, który warunkuje nie tylko uczenie się mowy, ale także kształtowanie wspólnego pola uwagi oraz wspólnej przestrzeni działania. Badacze G. Small, G. Vorgan [3] są zdania, że w początkowej fazie rozwoju kory mózgowej niemowlęcia istotne znaczenie ma obraz ludzkiej twarzy w procesie aktywowania neuronów lustrzanych (odkrytych przez Rizolattiego w latach 90. ubiegłego wieku) oraz formowania struktury ciała migdałowatego.

A. Meltzoff - amerykański psycholog z University of Washington, przeprowadził eksperyment, w którym pokazywał język swojemu synowi Ksawierowi (dwie godziny po narodzinach) i obserwował zachowanie dziecka. Okazało się, że noworodek po upływie kilku sekund odpowiedział tym samym (wystawił język). A. Meltzoff i K. Moor prowadzili dalsze badania (1977, 1983, 1989, 1994) [4-7], które potwierdziły, że noworodki wykazują prymitywną zdolność do imitowania ruchów twarzy swoich opiekunów. Natomiast wrodzona zdolność do imitacji odgrywa bardzo ważną rolę w dalszym rozwoju społecznym i poznawczym oraz stanowi swoisty fenomen ewolucyjny. Wczesna imitacja jest niepowtarzalnym, wrodzonym mechanizmem, który „programuje” matkę do miłości, do budowania więzi i odczytywania przez nią sygnałów wysyłanych przez dziecko. A. Meltzoff dowodzi, że imitacja u noworodków nie jest zachowaniem wyuczonym, ale mechanizmem wrodzonym. Naukowiec zaprojektował teoretyczny model AIM (Active Intermodal Mapping), który wyjaśnia to zjawisko. Noworodki nie widzą własnej twarzy, wobec tego nie mogą wykorzystać wzrokowego sprzężenia zwrotnego oraz mechanizmów korekty błędu, aby mogły nauczyć się takiej czynności. W takim razie w ich mózgach musi istnieć zaprogramowany mechanizm służący do odwzorowania wyglądu twarzy drugiej osoby i „przetłumaczenia" na neurony zarządzające ruchem [8]. Jednak około szóstego tygodnia życia te wrodzone zachowania stopniowo słabną [9]. W trzecim miesiącu życia niemowlę już nie imituje podstawowych ruchów twarzy, ale przechodzi na inne formy interakcji społecznych (naśladuje). Naśladowanie jako czynność świadoma i kontrolowana jest kluczową umiejętnością w rozwoju małego dziecka, dzięki której buduje ono kolejne umiejętności: język, interakcje społeczne, empatię, zabawę w udawanie. Wczesne naśladowanie jest związane $z$ wrodzoną aktywnością neuronów lustrzanych [10]. W związku z tym, jeżeli w sieci neuronów lustrzanych wystąpi defekt, to należy sądzić, że noworodki nie będą odpowiadały w badaniu reakcji odzwierciedlania (A. Meltzoff nazwał swój eksperyment „Like me”, przedstawione w artykule badanie nazwano „badaniem reakcji odzwierciedlania”). Natomiast brak imitacji może być pierwszym niepokojącym sygnałem autystycznego spektrum. Z kolei wczesna identyfikacja noworodków zagrożonych zaburzeniami autystycznymi umożliwi szybkie wdrożenie terapii i nakierowanie dziecka na prawidłowy tor rozwoju.

\section{Cel pracy}

Przedmiotem badań było sprawdzenie związku pomiędzy brakiem reakcji odzwierciedlania w okresie noworodkowym a zaburzeniami ze spektrum autyzmu w dalszym rozwoju dziecka.

\section{Materiał i metody}

Badania miały charakter dwuetapowy. W pierwszym etapie, który trwał od listopada 2016 r. do grudnia 2017 r. poddano nieinwazyjnemu badaniu reakcji odzwierciedlania losową grupę 350 noworodków, które w tym czasie przebywały na Oddziale Neonatologii z pododdziałem Patologii i Intensywnej Terapii Noworodka w Wojewódzkim Centrum Szpitalnym Kotliny Jeleniogórskiej. Badanie reakcji odzwierciedlania odbywało się zazwyczaj w drugiej dobie życia, w warunkach naturalnych (sale noworodkowe lub sala zabiegowa) w czasie wykonywanych czynności pielęgniarskich. Noworodki były spokojne, przebrane, nakarmione, ale nie bezpośrednio po karmieniu (istotne warunki badania, ponieważ noworodek, który krzyczy, nie patrzy na twarz osoby badającej lub noworodek, który jest nadmiernie najedzony, w charakterystyczny sposób wysuwa język). W przypadku wcześniaków brano pod uwagę wiek skorygowany. Ponadto nie badano reakcji odzwierciedlania u noworodków, wcześniaków, których stan zdrowia na to nie pozwalał (dzieci walczyły o życie, przebywały w inkubatorze, były podłączone do respiratora lub n-cepapu). Badanie odbywało się po ustabilizowaniu sytuacji zdrowotnej (dzieci wyjęte z inkubatorów, samodzielnie oddychały, ssały pokarm), najczęściej w drugiej dobie.

Podczas badania reakcji odzwierciedlania pokazywano język każdemu badanemu noworodkowi, czasami otwierano usta, (odległość ok. $30 \mathrm{~cm}$ ) i oczekiwano na odpowiedź ok. 10 s. Badanie kończyło się, gdy dziecko 
zareagowało pokazaniem języka lub nie pojawiła się reakcja odzwierciedlająca.

Utworzono grupę Ex (nazwaną „eksperymentalną") z 10 noworodków spośród 350, które nie odzwierciedlały oraz grupę Ek (nazwaną „porównawczą”) z losowo wybranych 20 noworodków spośród pozostałych 340, które odzwierciedlały. Następnie dokonano porównania sytuacji rodzinnej i zdrowotnej noworodków w obu badanych grupach w celu wykrycia czynników, które mogą wpływać na reakcję odzwierciedlającą.

W badaniu zastosowano metodę sondażu diagnostycznego z wykorzystaniem techniki wywiadu ustrukturyzowanego, uzupełnionego analizą dokumentacji medycznej. Pytania miały charakter zamknięty, były identyczne dla wszystkich matek, zadawane w tej samej kolejności. Wywiad składał się z pytań dotyczących, m.in.: wieku rodziców, wykształcenia rodziców, przebiegu ciąży, porodu (w którym tygodniu ciąży odbył się poród), punktacji w skali Apgar czy stanu zdrowia noworodka po porodzie. Następnie uzyskane dane zakodowano (utworzono tzw. zakodowaną bazę danych) i przeprowadzono analizę statystyczną przy użyciu pakietu IBM SPSS Statistics. Za jego pomocą wykonano test niezależności chi-kwadrat. W sytuacji, w której analizowany związek był statystycznie istotny, zbadano miarę siły związku Vc (V-Cramer). Za poziom istotności statystycznej uznano $p<0,05$.

Drugi etap badań trwał od grudnia 2017 r. do lutego 2019 r. W tym okresie skontrolowano rozwój dzieci (Ex, Ek) w ich osiemnastym miesiącu życia (dla wcześniaków był to wiek skorygowany) i sprawdzono, czy istnieje ewentualna zależność pomiędzy brakiem reakcji odzwierciedlania w okresie noworodkowym a rozwojem dzieci w kierunku autystycznego spektrum. W badaniu posłużono się „Kartami diagnozy - 10 etapów rozwoju dziecka od 4. do 36. miesiąca życia" [11], które są znanym narzędziem diagnostycznym wśród terapeutów, logopedów i pediatrów. Karty diagnozy dokładnie opisują najważniejsze umiejętności i osiągnięcia dziecka w poszczególnych miesiącach życia, pomagają w ocenie rozwoju oraz w wykryciu wszelkich nieprawidłowości. Badanie przebiegało w obecności rodzica/rodziców w rodzinnym domu dziecka, w jego naturalnym środowisku.

Na przeprowadzenie badań uzyskano zgodę ordynatora Oddziału Neonatologii, pielęgniarki oddziałowej, matek/rodziców dzieci oraz pozytywną opinię Uczelnianej Komisji ds. Etyki Badań Naukowych.

\section{Wyniki}

W celu zweryfikowania, czy zachodzi istotna statystycznie zależność pomiędzy odzwierciedlaniem a wiekiem matek i ojców, przeprowadzono test chi-kwadrat nie- zależności. W jego wyniku okazało się, że mierzone związki są nieistotne statystycznie $-\chi 2(2)<0,01 ; \mathrm{p}=$ 1,000 (matki); $\chi 2(2)=0,13 ; p=0,939$, a co za tym idzie zarówno w grupie eksperymentalnej i porównawczej brak jest zróżnicowania odnośnie wieku matek i ojców (Rycina 1).

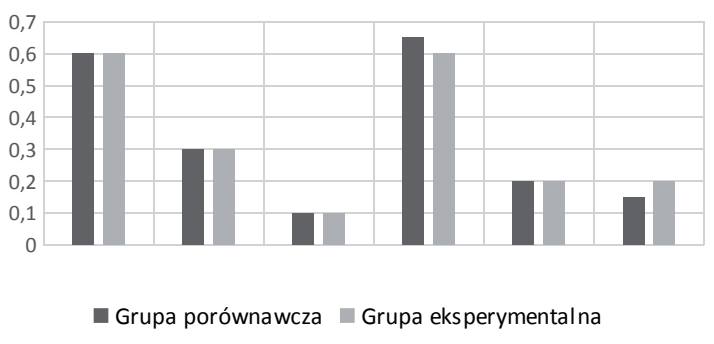

Rycina1. Rozkład procentowy związku pomiędzy odzwierciedlaniem a wiekiem matek i ojców

Figure 1. Analysis of the relationship between mirroring and mothers and fathers' age

Źródło: opracowanie własne

Source: author's own analysis

W kolejnym kroku, również za pomocą testu chi-kwadrat niezależności zbadano współzależność pomiędzy odzwierciedlaniem a wykształceniem matek i ojców. Istotny statystycznie okazał się wyłącznie związek wśród matek $-\chi^{2}(2)=6,25 ; p<0,05$. Matki dzieci, które nie odzwierciedlały w większości mają wykształcenie podstawowe/zawodowe lub wyższe, zaś dzieci odzwierciedlających - średnie. Współczynnik VC dowodzi, że jest to dość silna zależność. Wśród ojców natomiast brak jest związku między wykształceniem a odzwierciedlaniem ich dzieci $-\chi^{2}(2)=0,45 ; p=0,797$ (Rycina 2).

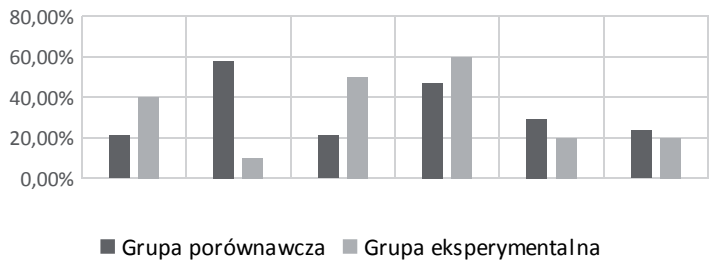

Rycina 2. Rozkład procentowy związku pomiędzy odzwierciedlaniem a wykształceniem matek i ojców

Figure 2. Analysis of the relationship between mirroring and mothers and fathers' education

Źródło: opracowanie własne

Source: author's own analysis

Następnie postanowiono zweryfikować, czy zachodzi istotna statystycznie zależność pomiędzy odzwierciedlaniem a wystąpieniem ciąży wysokiego ryzyka. Wynik wykonanego testu chi-kwadrat niezależności 
jest nieistotny statystycznie $-\chi^{2}(1)=0,08 ; p=0,784$, a rozkłady procentowe dowodzą, że zarówno w grupie eksperymentalnej, jak i w grupie porównawczej w większości wystąpiły ciąże wysokiego ryzyka (Rycina 3 ).

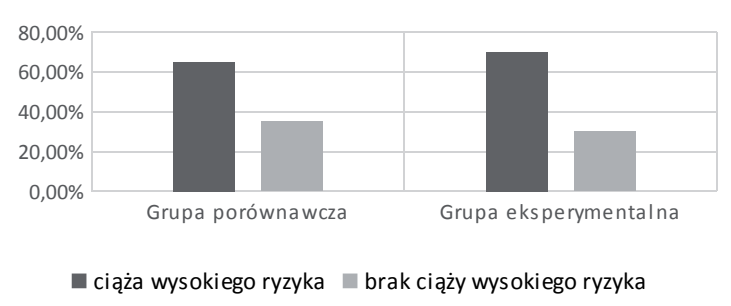

Rycina 3. Rozkład procentowy związku pomiędzy odzwierciedlaniem a ciążą wysokiego ryzyka

Figure 3. Analysis of the relationship between mirroring and high-risk pregnancy

Źródło: opracowanie własne

Source: author's own analysis

Nieistotny statystycznie okazał się być również związek pomiędzy odzwierciedlaniem a wcześniactwem $\chi^{2}(1)<0,01 ; p=1,000$. Rozkłady procentowe wskazują na identyczną zależność występowania wcześniactwa zarówno w grupie dzieci nieodzwierciedlających, jak i odzwierciedlających (Rycina 4).

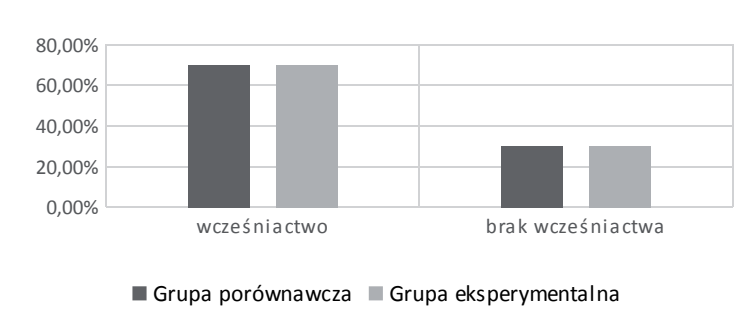

Rycina 4. Rozkład procentowy związku pomiędzy odzwierciedlaniem a wcześniactwem

Figure 4. Analysis of the relationship between mirroring and premature birth

Źródło: opracowanie własne

Source: author's own analysis

W następnym kroku, także przy użyciu testu chi-kwadrat niezależności, zbadano, czy odzwierciedlanie jest powiązane istotnie statystycznie z rodzajem porodu. Niemniej jednak i tym razem wynik okazał się być nieistotny statystycznie $-\chi^{2}(1)=0,94 ; p=0,333$. W większości matki dzieci odzwierciedlających, jak i nieodzwierciedlających miały cesarskie cięcie (Rycina 5).

W ostatnim kroku również został wykonany test chi-kwadrat w celu sprawdzenia współzależności pomiędzy odzwierciedlaniem a stanem zdrowia noworodka ocenionym na podstawie skali Apgar. Jednakże i tym razem wynik okazał się być nieistotny statystycznie $-\chi^{2}(1)$
$=0,39 ; p=0,823$, a więc brak jest związku pomiędzy poddanymi analizie zmiennymi. Badane dzieci zgodnie i w większości miały dobry stan zdrowia (Rycina 6).

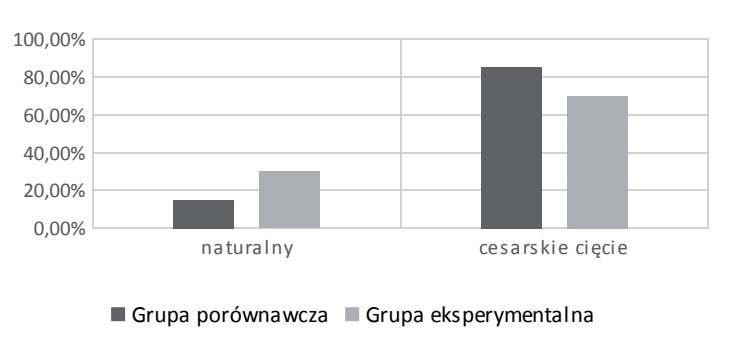

Rycina 5. Rozkład procentowy związku pomiędzy odzwierciedlaniem a rodzajem porodu

Figure 5. Analysis of the relationship between mirroring and delivery Źródło: opracowanie własne

Source: author's own analysis

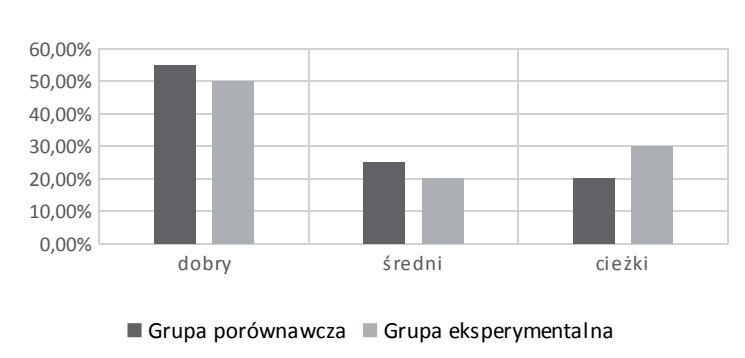

Rycina 6. Rozkład procentowy związku pomiędzy odzwierciedlaniem a stanem zdrowia noworodka

Figure 6. Analysis of the relationship between mirroring and health condition of the newborn

Źródło: opracowanie własne

Source: author's own analysis

W drugim etapie badań sprawdzono przebieg rozwoju dzieci (Ex, Ek) w ich 18. miesiącu życia. Okazało się, że na pięcioro dzieci z grupy Ex aż czworo wykazało niepokojące symptomy autyzmu. Z czwórki dzieci u dwójki z nich został zdiagnozowany i potwierdzony autyzm wczesnodziecięcy w poradni psychologiczno-pedagogicznej. Tymczasem dwójka dzieci, pomimo iż wykazywała zachowania ze spektrum autyzmu, nie była poddana dalszej diagnozie. Pośród dzieci (Ex), które w okresie noworodkowym nie odzwierciedlały, tylko jedna dziewczynka nie manifestowała zachowań autystycznych. W grupie dzieci (Ek), które w okresie noworodkowym odzwierciedlały nie stwierdzono niepokojących symptomów wskazujących na autyzm, pomimo że u dwójki dzieci w okresie ciąży i w okresie okołoporodowym wystąpiły czynniki silnie uszkadzające OUN mające ogromny wpływ na dalszy rozwój i jakość życia. Jednak u tych dzieci wykazano inne deficyty, m.in.: opóźnienie rozwoju psychomotorycznego, zaburzenia integracji sensorycznej, zaburzenia zachowania, 
trudność w skupieniu uwagi czy nadaktywność ruchową.

\section{Dyskusja}

W pierwszym etapie badań przeprowadzono nieinwazyjne badanie reakcji odzwierciedlania w losowej grupie 350 noworodków, które przebywały na Oddziale Neonatologii z pododdziałem Patologii i Intensywnej Terapii. Spośród tej grupy wyłoniono 10 dzieci nieodzwierciedlających (gr Ex) oraz utworzono grupę kontrolną (Ek). W kolejnym kroku dokonano analizy porównawczej sytuacji rodzinnej i zdrowotnej noworodków w obu badanych grupach w celu wykrycia czynników, które mogą wpływać na reakcję odzwierciedlającą. Z kolei w drugim etapie badań sprawdzono rozwój dzieci z grupy Ex (grupa Ex zmniejszyła się o połowę: dwójka dzieci zmarła na skutek powikłań związanych z chorobami współistniejącymi; rodzice dwójki dzieci zmienili dane adresowe; jedno dziecko zostało adoptowane. Wobec zaistniałej sytuacji nie sprawdzono, jak przebiega rozwój u tych dzieci i tym samym nie wiadomo, czy prezentowały/nie prezentowały one zachowania ze spektrum autyzmu) oraz dzieci z grupy Ek w ich osiemnastym miesiącu życia (dla wcześniaków był to wiek skorygowany) i sprawdzono, czy istnieje ewentualna zależność pomiędzy brakiem reakcji odzwierciedlania w okresie noworodkowym a rozwojem dzieci w kierunku autystycznego spektrum.

Badania własne nie wykazały czynnika/czynników, które mogą wpływać na reakcję odzwierciedlania u noworodków. Zatem odzwierciedlanie (imitacja, wg A. Meltzoffa) ma podłoże w neuronach lustrzanych, które działają niezależnie od naszej woli i jest umiejętnością wrodzoną. Na ten fakt wskazują polscy naukowcy J. Rostowski, T. Rostowska [12], którzy dowodzą, że zachowanie noworodka imitującego proste ruchy osoby dorosłej krótko po urodzeniu (wysuwa język, otwiera usta) wskazuje na wrodzone działanie neuronów lustrzanych. Tak więc, według innego badacza [13], jeżeli rozwój neuronów lustrzanych przebiega prawidłowo w życiu płodowym i niemowlęcym, to tym samym prawidłowo będzie przebiegał rozwój funkcji społecznych i emocjonalnych ważnych z punktu widzenia rozwoju komunikacji oraz nawiązywania relacji z innymi osobami. Twarz jest tą częścią ciała, której najczęściej używamy do wyrażania własnych emocji. Dzieci z autyzmem nie wykazują takiego zainteresowania. Noworodki, które nie odpowiadały w reakcji odzwierciedlania nie patrzyły, nie skupiały wzroku na twarzy badającego.

Badania prowadzone przez wielu naukowców, m.in.: Oberman, Ramachandran, Pineda, 2008; Wan, Demaine, Zipse, Norton, Schlaug, 2010; Melt- zoff, Marschal, 2018 [14-16] pokazały, że deficyt w sieci neuronowej oznacza, iż noworodki nie będą imitowały (nie zareagują w reakcji odzwierciedlania). Z kolei brak wczesnej imitacji jest pierwszym alarmującym objawem zaburzeń ze spektrum autyzmu [17, 18]. Z tego względu zakłócenie zdolności do imitacji, następnie do naśladowania, u dzieci z autyzmem stanowi poważny problem w budowaniu przez nie wiedzy o świecie.

Badanie reakcji odzwierciedlania u noworodków może okazać się świetnym kryterium diagnostycznym do identyfikacji dzieci zagrożonych rozwojem w kierunku autystycznego spektrum. Natomiast tak wczesna eksploracja niepokojących zachowań pozwoli na bardzo szybkie wdrożenie terapii w ramach wczesnej interwencji i wspomagania rozwoju małego dziecka.

\section{Wnioski}

1. Dziesięć na trzysta pięćdziesiąt noworodków nie odpowiedziało w odruchu odzwierciedlania.

2. Sytuacja rodzinna i zdrowotna w badanych grupach (Ex, Ek) nie miała wpływu na odpowiedź w badaniu reakcji odzwierciedlania. Prawdopodobnie to defekt w sieci neuronów lustrzanych (zwłaszcza) w obrębie połączeń synaptycznych jest przyczyną braku reakcji odzwierciedlania u noworodków.

3. Wyniki badań potwierdziły zachodzącą zależność pomiędzy brakiem reakcji odzwierciedlania w okresie noworodkowym a dalszym rozwojem dzieci (Ex) w kierunku autystycznego spektrum.

4. Badania były prowadzone na niewielkiej grupie badawczej i w przyszłości warto by było sprawdzić na nowej, większej populacji dzieci, czy wyniki są powtarzalne.

\section{Piśmiennictwo}

1. Sacrey L, Zwaigenbaum L, Bennett J. Early Infant Development and Intervention for Autism Spectrum Disorder. J Child Neurol. https://journals.sagepub.com/doi/abs /10.1177/088307381560150 [dostęp: 31. 08.2015].

2. Grabińska M, Talar A, Kurylak A, Kaźmierczak M, Zreda-Pikies A, Wróbel-Bania A. Społeczne funkcjonowanie dziecka z autyzmem. Przegląd Naukowo-Metodyczny. Edukacja dla Bezpieczeństwa. 2013; 3: 158-169.

3. Small G, Vorgan G. Mózg. Jak przetrwać technologiczną przemianę współczesnej umysłowości. Poznań: Wydawnictwo Wesper; 2011.

4. Meltzoff A, Moore K. Neonatal Imitation. https://www.researchgate.net. [dostęp: 22.02.2012].

5. Meltzoff A, Moore K. Newborn Infants Imitate Adult Facial Gestures. Child Development. 1983; 54: 702-709.

6. Meltzoff A, Moore K. Imitation in Newborn Infants: Exploring the Range of Gestures Imitated and the Underlying Mechanisms. Dev Psychol. 1989; 6: 95. 
7. Meltzoff A, Moore K. Imitation, memory, and the representation of persons. Infant Behav Dev. 1994; 17: 83-99.

8. Starczewski T. Neurony lustrzane - od akcji do empatii. Bona Vita. http://bonavita.pl/neurony-lustrzane-od-akcjido-empatii [dodano: 03.05.2016].

9. Keven N, Akins K. Neonatal imitation in context: Sensorimotor development in the perinatal period. Behav Brain Sci. 2017; 40: 1-58.

10. GalleseV, Rizzolatti G, Fogassi L. Mirrors in the mind. Sci Am. 2006; 295, 5: 54-61.

11. Cieszyńska J, Korendo M. Karty diagnozy. 10 etapów rozwoju dziecka od 4. do 36. Kraków: Wydawnictwo Edukacyjne; 2008.

12. Rostowski J, Rostowska T. The Role of The Mirror Neuron System In Development of Language And Interpersonal Communication. Dev Psychol. 2014; 2: 51-65.

13. Iacoboni M. Imitation, Empathy, and Mirror Neurons. Annu Rev Psychol. 2009; 60: 653-70.

14. Oberman L, Ramachandran S, Pineda J. Modulation of mu suppression in children with autism spectrum disorders in response to familiar or unfamiliar stimuli: The mirror neuron hypothesis. Neuropsychology. 2008; 46: 1558-1565.

15. Wan C, Demaine K, Zipse L, Norton A, Schlaug G. From music making to speaking: engaging the mirror neuronsystem in autism. Brain Res Bull. 2010; 82, 3-4: 161-168.

16. Meltzoff A, Marschal P. Human infant imitation as a social survival circuit. Curr Opin Behav Sci. 2018; 24: 130-136.
17. lacoboni $M$, Dapretto $M$. The mirror neuron system and the consequences of its dysfunction. Nat Rev Neurosci. 2006; 7, 12: 942-951.

18. Hamilton A. Reflecting on the mirror neuron system in autism: A systematic review of current theories. Developmental Cognitive Neuroscience. 2013; 3: 91-105. https://www. ncbi.nlm.nih.gov/pubmed/23245224 [dostęp: 13.10.2019].

Artykuł przyjęty do redakcji: 15.05.2020.

Artykuł przyjęty do publikacji: 20.05.2021.

Źródło finansowania: Praca nie jest finansowana z żadnego źródła. Konflikt interesów: Autorzy deklarują brak konfliktu interesów.

\author{
Adres do korespondencji: \\ Dorota Prędkiewicz \\ ul. Strzegomska 55 \\ 53-611 Wrocław \\ e-mail: stado5predki@op.pl \\ Wydział Nauk Stosowanych, \\ Dolnośląska Szkoła Wyższa we Wrocławiu
}

